\title{
Documentation of Additional Vessels from the Johns Site (41CP12), Camp County, Texas
}

Timothy K. Perttula

Heritage Research Center, Stephen F. Austin State University

Bo Nelson

Heritage Research Center, Stephen F. Austin State University

Mark Walters

Heritage Research Center, Stephen F. Austin State University

Follow this and additional works at: https://scholarworks.sfasu.edu/ita

Part of the American Material Culture Commons, Archaeological Anthropology Commons, Environmental Studies Commons, Other American Studies Commons, Other Arts and Humanities Commons, Other History of Art, Architecture, and Archaeology Commons, and the United States History Commons

Tell us how this article helped you.

This Article is brought to you for free and open access by the Center for Regional Heritage Research at SFA ScholarWorks. It has been accepted for inclusion in Index of Texas Archaeology: Open Access Gray Literature from the Lone Star State by an authorized editor of SFA ScholarWorks. For more information, please contact cdsscholarworks@sfasu.edu. 
Documentation of Additional Vessels from the Johns Site (41CP12), Camp County, Texas

\section{Creative Commons License}

\section{(c) (1) \&}

This work is licensed under a Creative Commons Attribution-NonCommercial 4.0 International License 


\title{
Documentation of Additional Vessels from the Johns Site (41CP12), Camp County, Texas
}

\author{
Timothy K. Perttula, Bo Nelson, and Mark Walters
}

\section{INTRODUCTION}

The Johns site (41CP12) (Figure 1) is a Titus phase cemetery in the Prairie Creek valley in the Big Cypress Creek stream basin of the Northeast Texas Pineywoods (Diggs et al. 2006:Figures 1-3). The Caddo artifacts from the site are from the Robert $\mathrm{L}$. Turner, Jr. and Tommy John collections. Both men are current residents of Camp County, Texas.

A total of 35 Late Caddo (ca. A.D. 1400-1680), Titus phase, burials were excavated between May 1966 and December 1984 at the Johns site. The first 19 burials were excavated by Tommy Johns and Robert L. Turner, Jr., and Johns continued to excavate burials at the site until 1984. No single map of the plan of the Johns site cemetery exists in the available notes, but enough information is provided to reconstruct the arrangement and extent of the burial interments. The burials occur in a number of east-west rows (Figure 2), with the head of the deceased oriented almost always to face to the west. The deceased were placed in long, narrow, and relatively deep burial pits in an extended supine position, with funerary offerings generally placed along both the sides of the body and at the feet. Funerary offerings consisted of ceramic vessels (3-16 vessels per burial), ceramic pipes, arrow points (usually in quivers), celts, smoothing stones, as well as scrapers and other chipped stone tools. All of the burials have ceramic vessel funerary offerings, but only a small proportion had either ceramic pipes $(25.7 \%$ of the burials), arrow points (62.9\% of the burials), celts
(17.1\% of the burials), or other stone tools $(17.1 \%$ of the burials) placed in the burial pit.

In the summer of 2009, the Robert L. Turner, Jr. vessel and pipe collection and the Tommy Johns collection of vessels, pipes, celts, and arrow points were fully documented from the Johns site. A detailed description of each ceramic vessel or ceramic pipe was made for documentation purposes, accompanied by drawings appended to vessel documentation forms (on file, Archeological \& Environmental Consultants, LLC files in Austin, Texas), where needed, of ceramic vessel decorative motifs or pipe morphology to supplement the artifact descriptions. Analysis notes and photographs were also obtained on the arrow points, celts, and other stone artifacts from a number of burials in the Johns collection (Perttula et al. 2010).

A total of 277 ceramic vessels were documented in the Turner and Johns collections from the Johns site (Perttula et al. 2010). Subsequent to the completion of the published report, Tommy Johns located six additional vessels from the Johns site cemetery in his collection, and these vessels were documented in January 2010. This article provides information on the six previously undocumented vessels from the Johns site, increasing the total number of vessels to $283 .^{1}$

With the larger sample of 283 vessels, the vessels from the Johns site are dominated by engraved fine wares $(68.1 \%$, Table 1$)$. Utility wares comprise $25.5 \%$ of the ceramic vessel mortuary offerings, and plain wares another $6.4 \%$. 


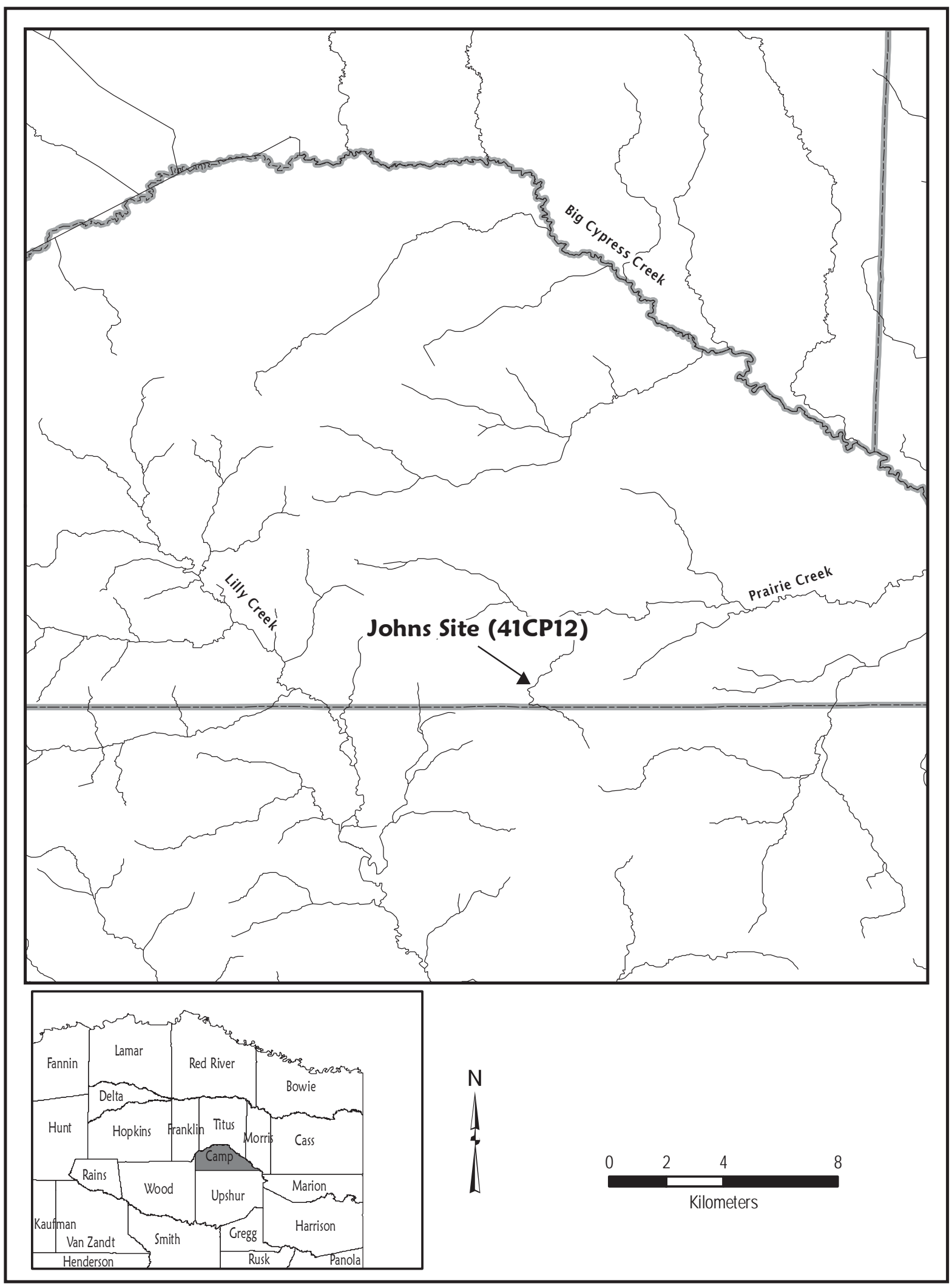

Figure 1. Location of Camp County in East Texas and the location of the Johns site (41CP12) within the county. 


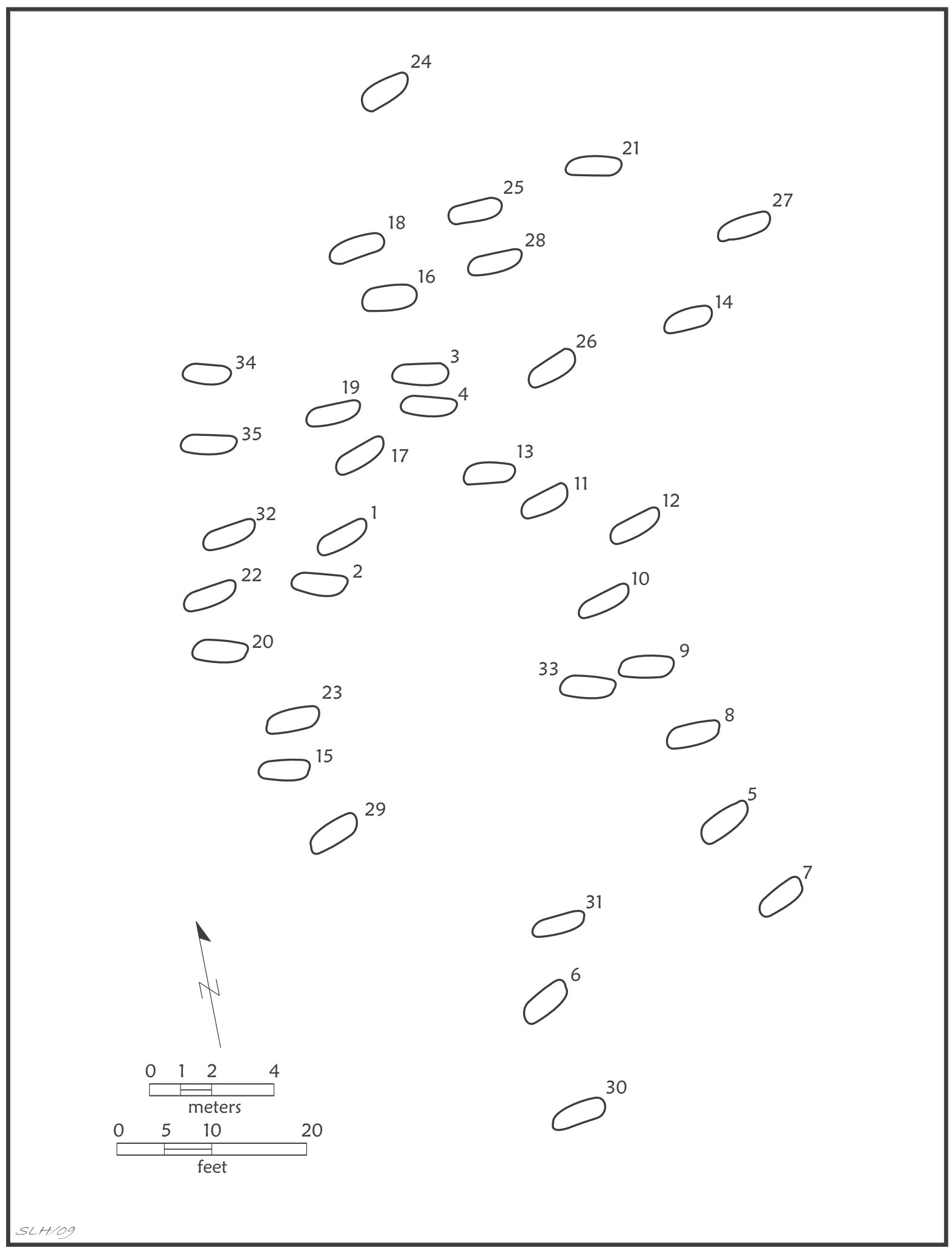

Figure 2. Map of the Johns site cemetery. 
Table 1. Vessels Forms at the Johns site.

\begin{tabular}{lcccr}
\hline Vessel Forms & Fine wares & Utility wares & Plain wares & N \\
\hline Jar & 4 & 69 & 3 & 76 \\
Carinated bowl & 104 & - & 5 & 109 \\
Compound bowl & 34 & - & 1 & 35 \\
Bowl & 14 & 2 & 8 & 24 \\
Effigy bowl & 1 & - & - & 1 \\
Chalice & 1 & - & - & 1 \\
Bottle & 31 & - & - & 32 \\
Olla & 3 & 1 & - & 2 \\
Compound vessel & 1 & 72 & 18 & 283 \\
\hline Totals & 193 & & & 2 \\
\hline
\end{tabular}

*The fine ware compound or conjoined vessel is a bottle-compound bowl; the utility ware vessel is a bowl-jar combination.

\section{VESSEL RECORDATION FORMS}

SITE NAME OR SITE NUMBER: Johns (41CP12)

VESSEL NO.: Burial 3, Pot 7

NON-PLASTICS: grog

VESSEL FORM: Carinated bowl

RIM AND LIP FORM: Direct rim with a rounded, exterior folded lip

CORE COLOR: F (fired in a reducing environment and cooled in the open air)

INTERIOR SURFACE COLOR: brown (10YR 4/3)

EXTERIOR SURFACE COLOR: brown (10YR 4/3)

WALL THICKNESS (RIM, BODY, AND BASE IN MM): 6.9 mm, rim; $6.7 \mathrm{~mm}$, body; $7.3 \mathrm{~mm}$, base

INTERIOR SURFACE TREATMENT: smoothed on the rim

EXTERIOR SURFACE TREATMENT: burnished

HEIGHT (IN CM): 17.0

ORIFICE DIAMETER (IN CM): 30.0

DIAMETER AT BOTTOM OF RIM OR NECK (IN CM): 16.7 


\section{BASE DIAMETER (IN CM): 6.7+}

\section{ESTIMATED VOLUME (IN LITERS): 4.6 liters}

DECORATION: The rim panel has five upper and lower sets of engraved alternating nested triangles (Figure 3). Each nested triangle has ovals or negative ovals within them delineating by engraved, excised, or cross-hatched zones or small triangular areas. One of the ovals has a small central engraved dot within it.

TYPE: Ripley Engraved, var. Williams (see Perttula et al. 2010:Figure 2h)

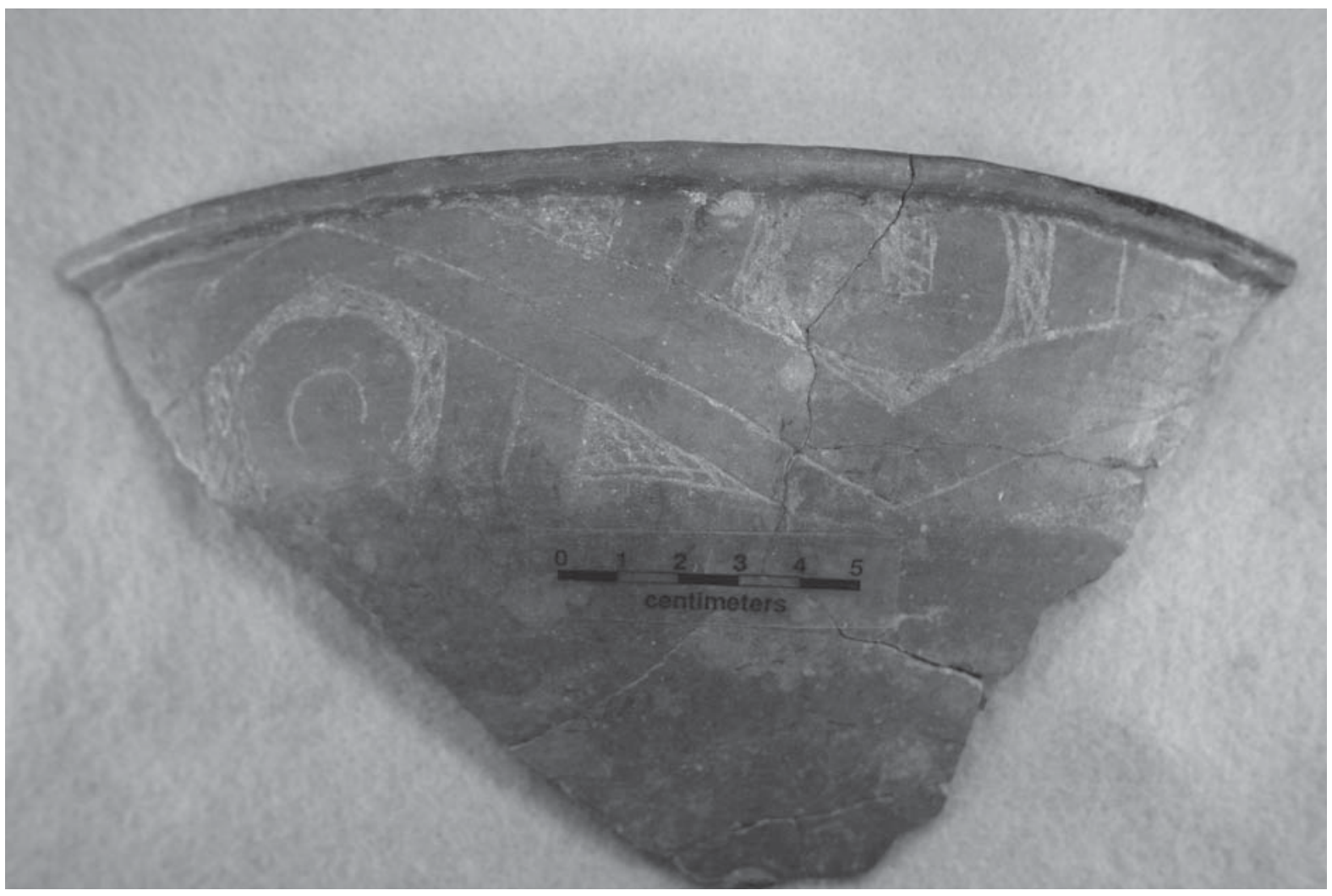

Figure 3. Ripley Engraved, var. Williams carinated bowl (Burial 3, Pot 7) from the Johns site.

SITE NAME OR SITE NUMBER: Johns (41CP12)

VESSEL NO.: Burial 11, Pot 8

NON-PLASTICS: grog and bone; sandy paste

VESSEL FORM: Carinated bowl

RIM AND LIP FORM: Direct rim and a rounded, exterior folded lip

CORE COLOR: $\mathrm{G}$ (fired in a reducing environment and cooled in the open air)

INTERIOR SURFACE COLOR: very dark grayish-brown (10YR 3/2) 
EXTERIOR SURFACE COLOR: red (2.5YR 4/6)

WALL THICKNESS (RIM, BODY, AND BASE IN MM): $5.6 \mathrm{~mm}$, rim; $6.6 \mathrm{~mm}$, body; $8.7 \mathrm{~mm}$, base INTERIOR SURFACE TREATMENT: smoothed on the rim

EXTERIOR SURFACE TREATMENT: burnished on the rim and smoothed on the body

HEIGHT (IN CM): 7.5

ORIFICE DIAMETER (IN CM): 16.0

DIAMETER AT BOTTOM OF RIM OR NECK (IN CM): 16.0

BASE DIAMETER (IN CM): 5.3

ESTIMATED VOLUME (IN LITERS): 0.72 liters

DECORATION: Exterior vessel surface is red-slipped (Figure 4)

TYPE: Unidentified fine ware

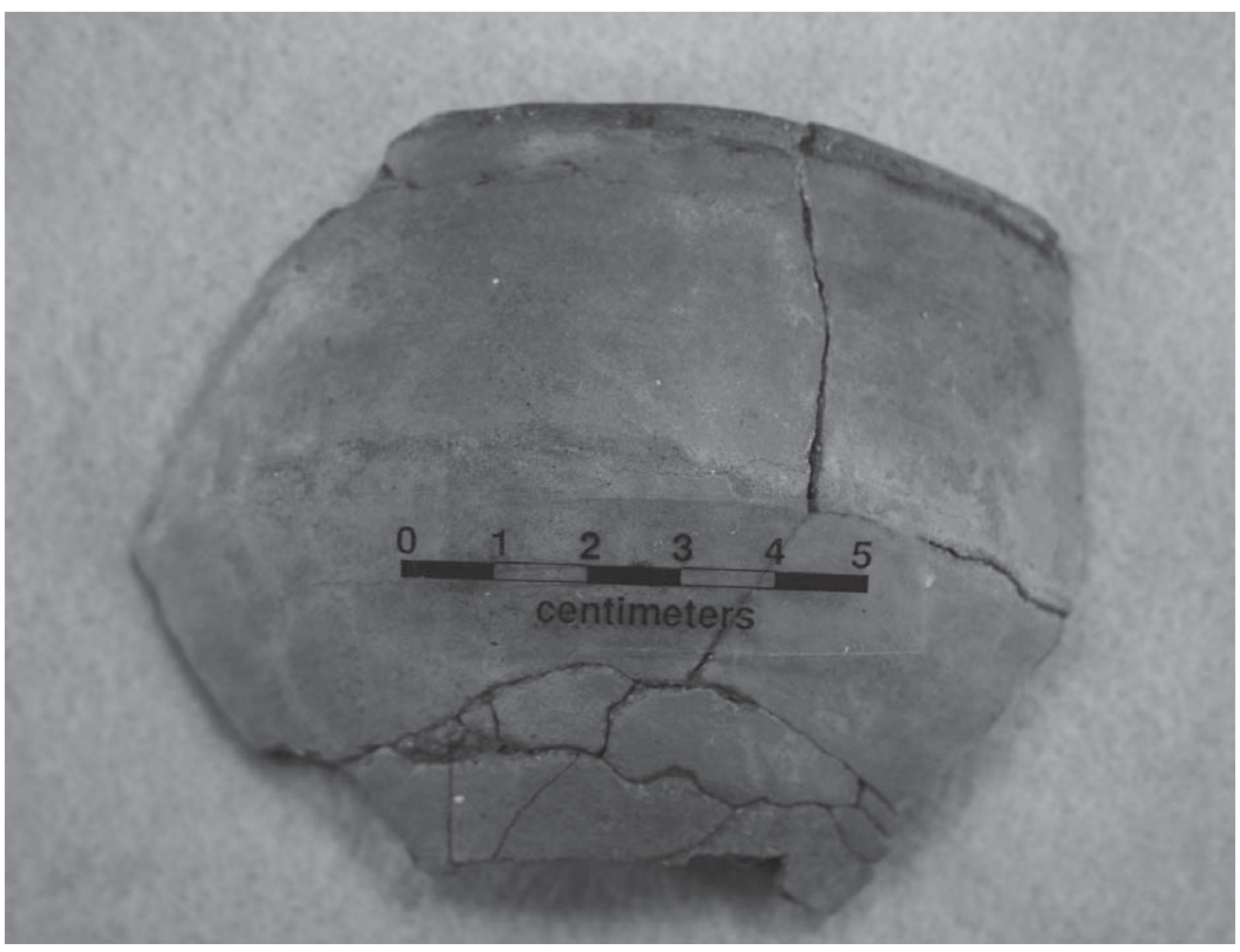

Figure 4. Red-slipped carinated bowl, Burial 11, Pot 8, from the Johns site. 
SITE NAME OR SITE NUMBER: Johns (41CP12)

VESSEL NO.: Burial 16, Pot 5

NON-PLASTICS: bone and grog

VESSEL FORM: Carinated bowl with four rim peaks

RIM AND LIP FORM: Everted rim and a rounded lip

CORE COLOR: B (fired and cooled in a reducing environment)

INTERIOR SURFACE COLOR: very dark grayish-brown (10YR 3/2)

EXTERIOR SURFACE COLOR: very dark grayish-brown (10YR 3/2)

WALL THICKNESS (RIM, BODY, AND BASE IN MM): $7.6 \mathrm{~mm}$, rim; $7.4 \mathrm{~mm}$, body

INTERIOR SURFACE TREATMENT: smoothed on the upper rim panel

EXTERIOR SURFACE TREATMENT: burnished on the upper and lower rim panels, and smoothed on the body

HEIGHT (IN CM): 8.8

ORIFICE DIAMETER (IN CM): 15.5

DIAMETER AT BOTTOM OF RIM OR NECK (IN CM): 13.6

BASE DIAMETER (IN CM): 7.0

ESTIMATED VOLUME (IN LITERS): 1.1 liters

DECORATION: The upper rim panel and rim peaks have S-shaped engraved ovals under the rim peaks, with short curvilinear engraved lines along the upper rim panel itself (Figure 5). The lower rim panel has an engraved scroll and circle motif repeated six times around the vessel; the central circle is centered under the rim peaks and the S-shaped ovals on the upper panel. A white kaolin clay pigment has been rubbed in the engraved lines.

TYPE: Ripley Engraved, var. Galt (see Perttula et al. 2010:Figure 2c) 


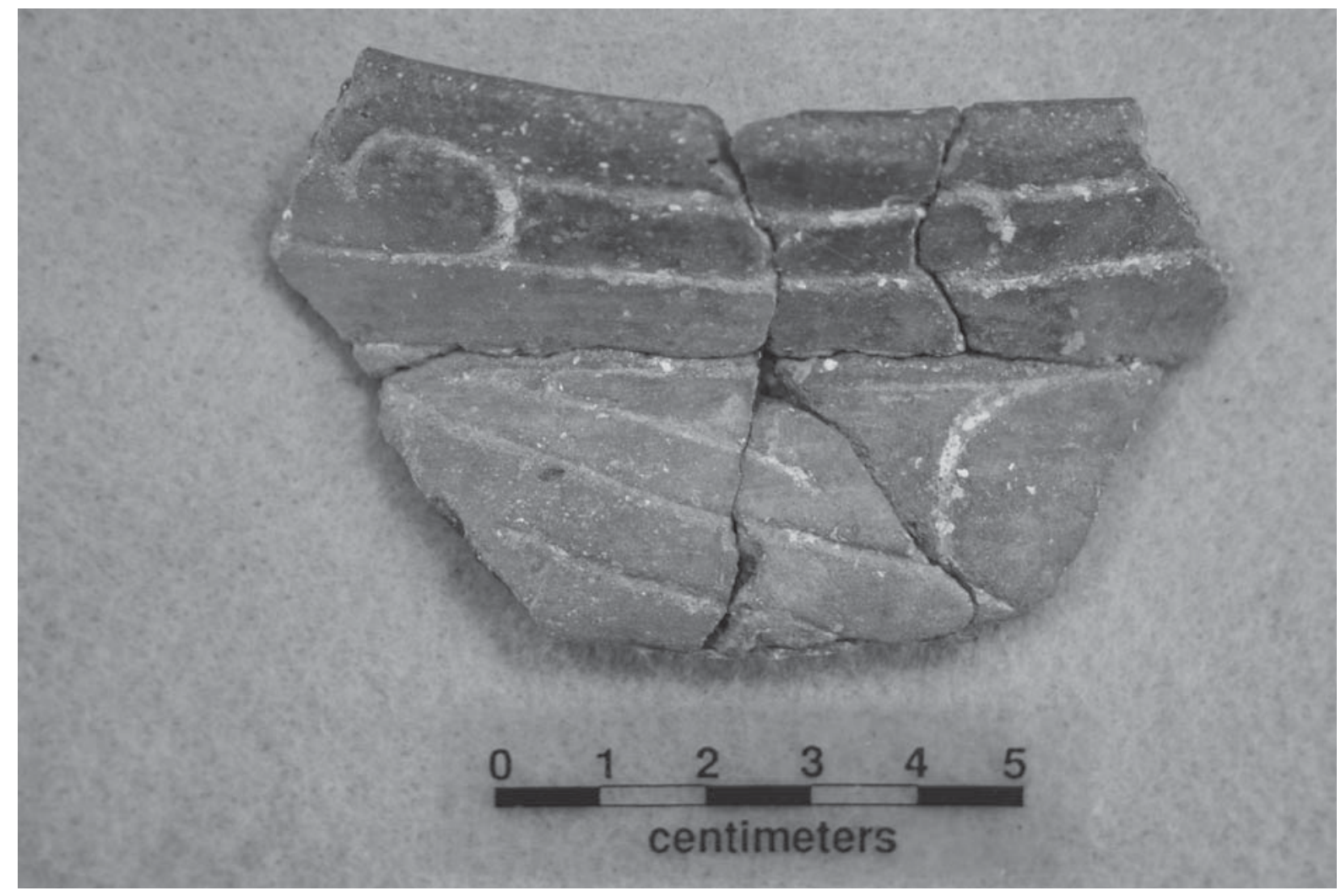

Figure 5. Rim sherds from Ripley Engraved, var. Galt compound bowl, Burial 16, Pot 5, from the Johns site.

SITE NAME OR SITE NUMBER: Johns (41CP12)

VESSEL NO.: Burial 21, Pot 3

NON-PLASTICS: grog

VESSEL FORM: Carinated bowl

RIM AND LIP FORM: Direct rim and a flat lip

CORE COLOR: F (fired in a reducing environment and cooled in the open air)

INTERIOR SURFACE COLOR: yellowish-brown (10YR 5/4); fire clouding on the rim and the upper body EXTERIOR SURFACE COLOR: yellowish-brown (10YR 5/4); fire clouding on the rim and the upper body WALL THICKNESS (RIM, BODY, AND BASE IN MM): $7.2 \mathrm{~mm}$, rim; $6.7 \mathrm{~mm}$, body INTERIOR SURFACE TREATMENT: burnished EXTERIOR SURFACE TREATMENT: burnished HEIGHT (IN CM): 19.4+ 
ORIFICE DIAMETER (IN CM): 29.0

DIAMETER AT BOTTOM OF RIM OR NECK (IN CM): 29.1

BASE DIAMETER (IN CM): N/A

ESTIMATED VOLUME (IN LITERS): 5.0+ liters

DECORATION: The rim panel has a continuous series of narrow engraved panels filled with small punctations etched in the clay after the vessel was fired (Figure 6). The panels (at least 20, but the total number is not known) change from vertical, diagonal, and opposed in orientation around the vessel. A red hematite-rich clay pigment has been rubbed in the engraved and punctated decorative elements.

TYPE: Unidentified fine ware vessel

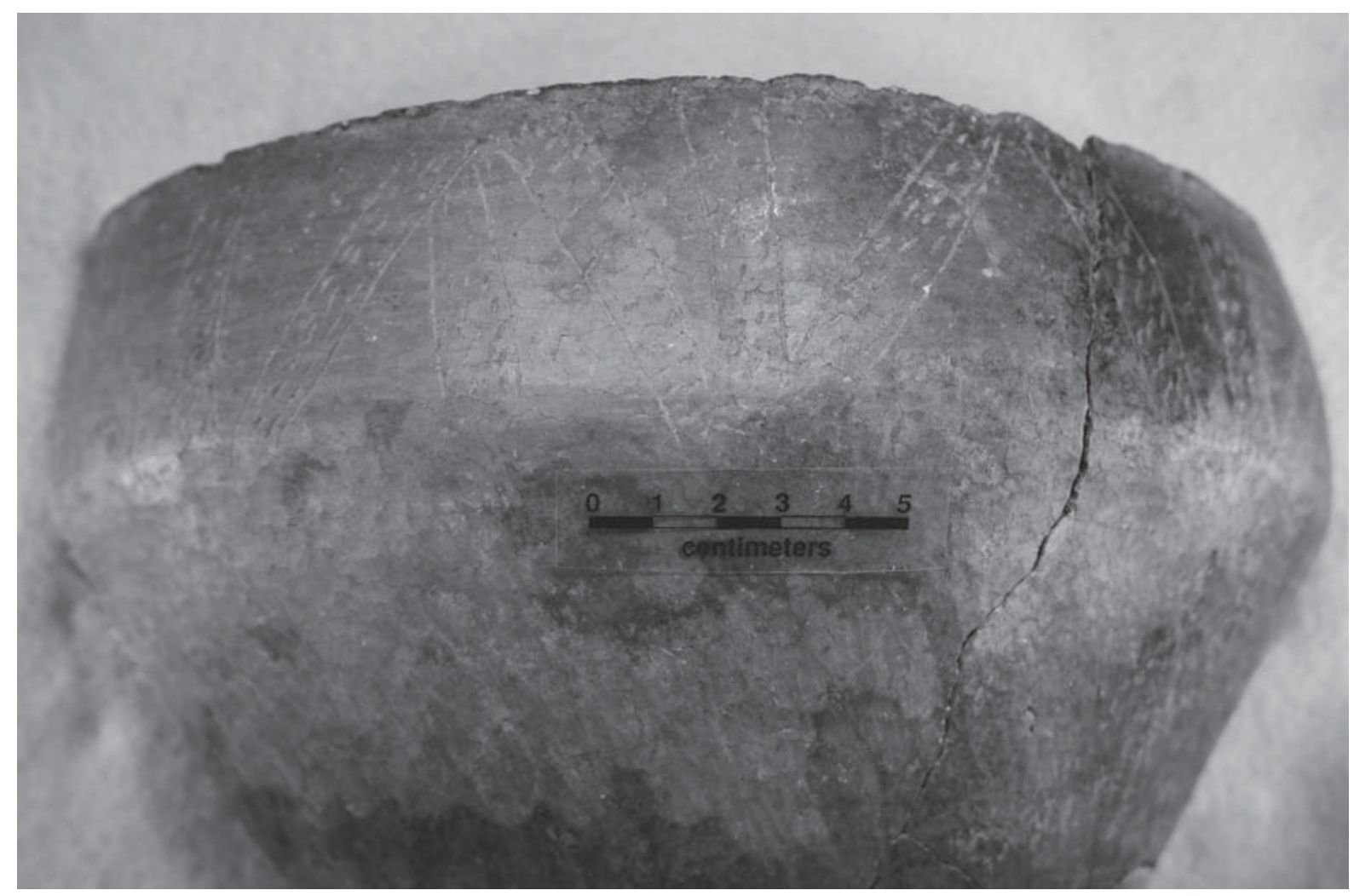

Figure 6. Engraved-punctated carinated bowl, Burial 21, Pot 3, from the Johns site.

SITE NAME OR SITE NUMBER: Johns

VESSEL NO.: Burial 28, Pot 9

NON-PLASTICS: grog

VESSEL FORM: Deep bowl (Figure 7)

RIM AND LIP FORM: Inverted rim and a rounded lip 


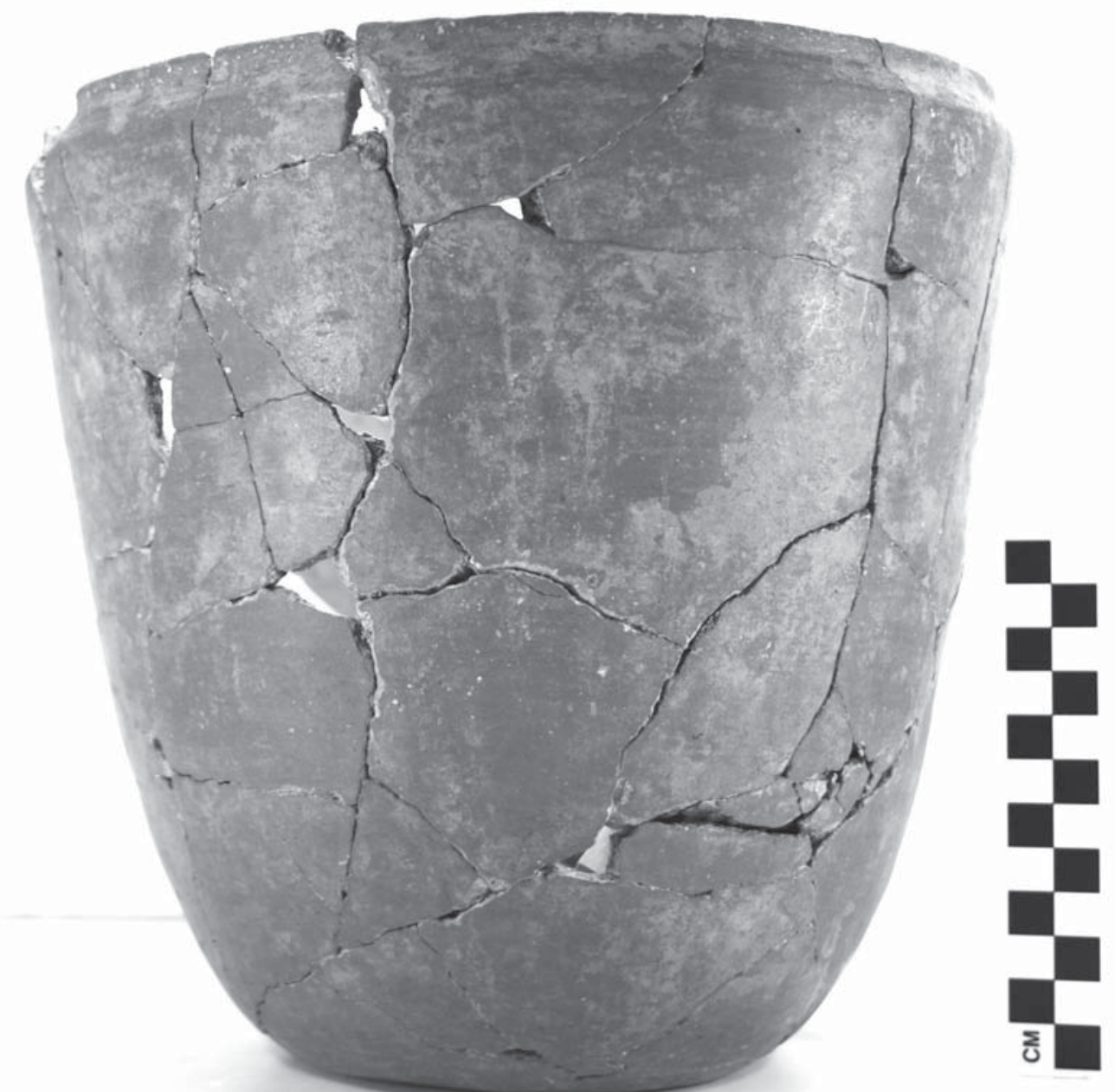

Figure 7. cf. Simms Plain red-slipped deep bowl, Burial 28, Pot 9 from the Johns site.

CORE COLOR: F (fired in a reducing environment and cooled in the open air)

INTERIOR SURFACE COLOR: red (2.5YR 4/8)

EXTERIOR SURFACE COLOR: red (2.5YR 4/8)

WALL THICKNESS (RIM, BODY, AND BASE IN MM): $5.5 \mathrm{~mm}$, rim

INTERIOR SURFACE TREATMENT: smoothed

EXTERIOR SURFACE TREATMENT: burnished

HEIGHT (IN CM): 21.7

ORIFICE DIAMETER (IN CM): 22.7 
DIAMETER AT BOTTOM OF RIM OR NECK (IN CM): 23.1

BASE DIAMETER (IN CM): 10.8

ESTIMATED VOLUME (IN LITERS): 3.9 liters

DECORATION: The vessel has a red slip on both interior and exterior vessel surfaces (Figure 7).

TYPE: cf. Simms Plain, based on vessel shape (see Suhm and Jelks 1962:Plate 71e)

SITE NAME OR SITE NUMBER: Johns (41CP12)

VESSEL NO.: Burial 31, Pot 4

NON-PLASTICS: grog

VESSEL FORM: Bottle

RIM AND LIP FORM: unidentified

CORE COLOR: $\mathrm{G}$ (fired in a reducing environment and cooled in the open air)

INTERIOR SURFACE COLOR: black (10YR 2/1)

EXTERIOR SURFACE COLOR: yellowish-brown (10YR 5/4)

WALL THICKNESS (RIM, BODY, AND BASE IN MM): 3.7 mm, neck; $4.1 \mathrm{~mm}$, body; $10.3 \mathrm{~mm}$, base

INTERIOR SURFACE TREATMENT: none

EXTERIOR SURFACE TREATMENT: burnished on the neck and body

HEIGHT (IN CM): N/A

ORIFICE DIAMETER (IN CM): N/A

DIAMETER AT BOTTOM OF RIM OR NECK (IN CM): N/A

BASE DIAMETER (IN CM): 9.4

ESTIMATED VOLUME (IN LITERS): N/A

DECORATION: The vessel body has an unknown number of sets of curvilinear scrolls whose upper and lower arms circle around each other and meet at a large central cross-hatched engraved circle (Figure 8). There are also at least three horizontal engraved lines encircling the top of the vessel body. The arms of the scroll begin from upper and lower body triangles and have widened and cross-hatched engraved arms on either side of the central engraved circle. A red hematite-rich clay pigment was also rubbed in the engraved lines.

TYPE: Wilder Engraved, var. Wilder (Perttula et al. 2010:Figure 4a-c) 


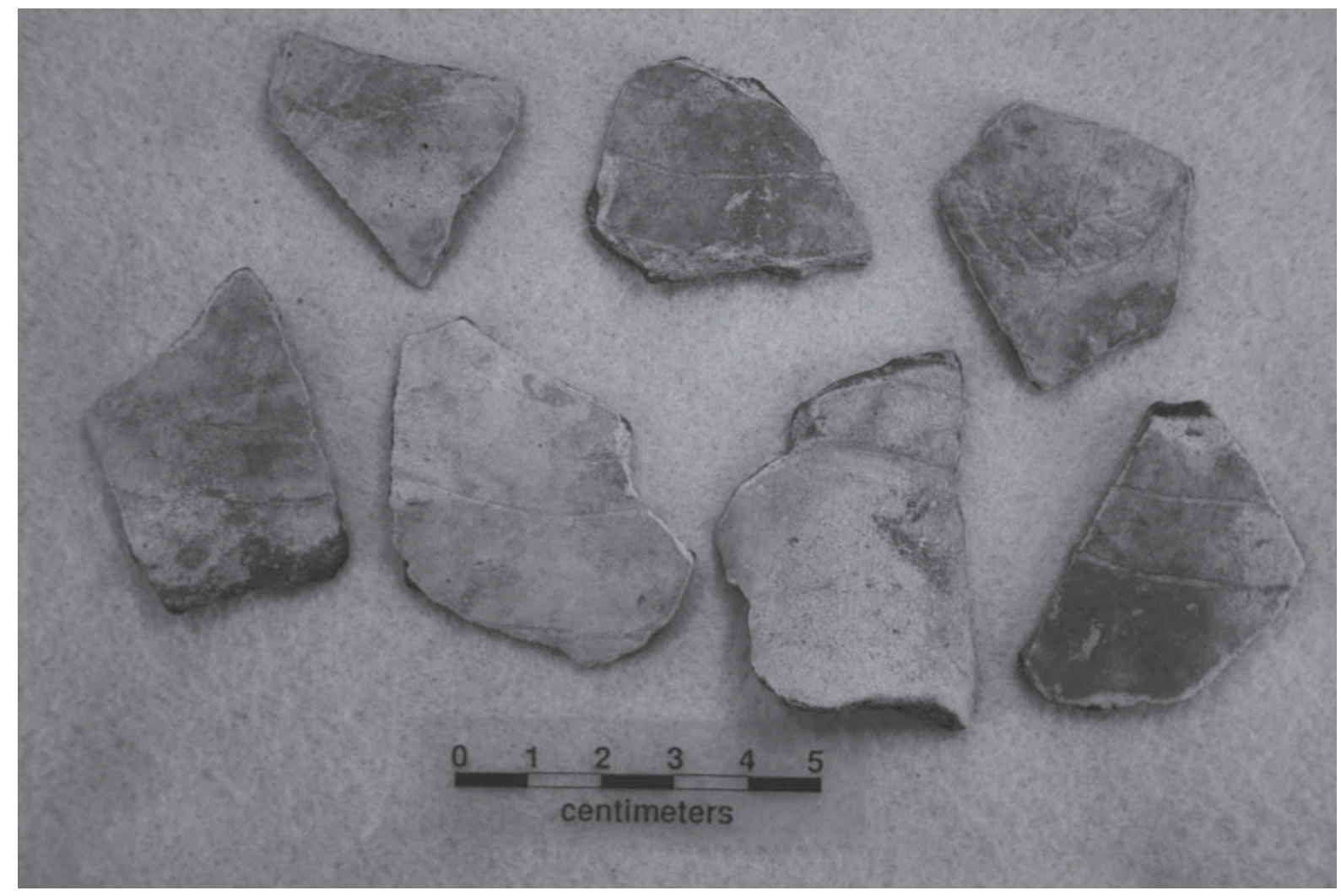

Figure 8. Wilder Engraved, var. Wilder bottle sherds, Burial 31, Pot 4.

\section{SUMMARY AND CONCLUSIONS}

This article reports on an additional six Titus phase ceramic vessels from the Johns site (41CP12) in the Tommy Johns collection. Perttula et al. (2010) discuss a sample of 277 vessels in the Tommy Johns and Robert L. Turner, Jr. collections from the site.

The Johns site (41CP12) appears to have been used by Caddo peoples as a place of burial interments for kin-related families or lineages for perhaps as long as ca. 170 years, from the beginning of the Titus phase at ca. A.D. 1430 to the start of the $17^{\text {th }}$ century A.D. (Perttula et al. 2010:271-274). From the available evidence, the main use of the site took place during much of the $15^{\text {th }}$ century A.D. and some portion of the $16^{\text {th }}$ century A.D. During that time, the Johns site cemetery grew from an early and relatively centrallyplaced cluster of burials (Episode A) covering a ca. 10.7 × $7.3 \mathrm{~m}$ area (see Perttula et al. 2010:Figure 280) to an expanded cemetery with added rows of later burials (Episodes B and C) and single interments (Episode D) in all directions from the Episode A burials. Common funerary offerings in these burials included Perdiz and Bassett arrow points, and several ceramic vessel varieties of Ripley Engraved (primarily var. Cash, var. Caldwell, var. Carpenter, var. Reed, var. Williams, var. Galt, and var. Gandy), Wilder Engraved, var. Wilder, Johns Engraved, and Turner Engraved fine wares and an assortment of utility ware vessels. At the abandonment of the Johns site cemetery by a local Titus phase Caddo group, the overall size of the cemetery was ca. $38 \mathrm{~m}$ north-south and $22 \mathrm{~m}$ east-west.

\section{END NOTE}

1. An additional vessel (Burial 22, Pot 9) was given to a friend of Tommy Johns' in the 1970s, and we have no information about it.

\section{REFERENCES CITED}

Diggs, G. M., B. L. Lipscomb, M. D. Reed, and R. J. O'Kennon 2006 Illustrated Flora of East Texas, Volume One. Botanical Research Institute of Texas, Fort Worth. 
Perttula, T. K., M. Walters, and B. Nelson

2010 Caddo Pottery Vessels and Pipes from the Johns Site (41CP12) in the Big Cypress Creek Basin in the Turner and Johns Collections, Camp County, Texas. Special Publication No. 11. Friends of Northeast Texas Archaeology, Austin and Pittsburg.
Suhm, Dee Ann and Edward B. Jelks (editors)

1962 Handbook of Texas Archeology: Type Descriptions. Texas Archeological Society Special Publication 1 and Texas Memorial Museum Bulletin 4, The University of Texas at Austin. 